\title{
Dampak Pendemi Covid 19 Terhadap PerubahanShift Kerja Dan Kinerja Cleaning Service
}

\author{
Eva Marsusanti ${ }^{1}$, Andi Riyanto ${ }^{2}$, Resti Yulistria ${ }^{3}$, Rifa Nurafifah Syabaniah ${ }^{4}$, Rusli \\ Nugraha $^{5}$ \\ 1,2,3,4,5 Universitas Bina Sarana Informatika \\ e-mail: ${ }^{1}$ eva.emr@bsi.ac.id, ${ }^{2} a n d i . i i o @ b s i . a c . i d,{ }^{3}$ resti.res@bsi.ac.id, ${ }^{4}$ rifa.rrf@bsi.ac.id, \\ 5rusli.rng@bsi.ac.id
}

\begin{abstract}
Abstrak
Pandemi Covid-19 berdampak terhadap segala aspek kehidupan manusia. Tidak terkecuali di lingkungan kerja perusahaan yang harus mengikuti kondisi saat ini. Tujuan penelitian ini berupaya mencari seberapa jauh dampak yang diakibatkan oleh pandemi terhadap perubahan shift kerja dan kinerja dari cleaning service. Metode deskriptif kuantitatif diterapkan pada penelitian ini. Sampel berjumlah 10 orang cleaning service yang bekerja di Citimall, Sukabumi. Pengumpulan data primer menggunakan metode observasi, wawancara, kuesioner dan studi pustaka yang kemudian diolah menggunakan uji statistic untuk membuktikan hipotesis. Hasil penelitian yang didapat menyimpulkan bahwa pandemi Covid-19 secara tidak langsung mempengaruhi perubahan shift kerja dan kinerja cleaning service. secara parsial Pandemi COVID 19 (X) berdampak signifikan terhadap Perubahan Shift Kerja (Y1), artinya setiap dampak yang diakibatkan oleh pandemic covid 19. Secara tidak langsung mempengaruhi perubaan shift kerja dan Kinerja Cleaning Service (Y2) Citimall Sukabumi. Variabel Pandemi covid $19(X)$ secara simultan dan signifikan memiliki pengaruh terhadap perubahan shift kerja (Y1) dan Kinerja Cleaning Service (Y2).
\end{abstract}

Kata kunci: Pandemi Covid-19, Shift kerja, Kinerja Cleaning Service

\begin{abstract}
The Covid-19 pandemic has impacted all aspects of human life. Not in a company work environment that has to keep up with current conditions. The purpose of this study was to find out how far the impact of the pandemic on changes in work shifts and the performance of cleaning services. Quantitative descriptive method was applied in this research. The sample visited 10 cleaning service people who worked at Citimall, Sukabumi. Primary data collection using observation, interviews, questionnaires and literature studies which are then processed using statistical tests to prove the hypothesis. The results of the study concluded that the Covid19 pandemic indirectly affected changes in work shifts and the performance of cleaning services. partially The COVID 19 (X) pandemic has a significant impact on Changes in Work Shifts (Y1), meaning that any impacts caused by the covid 19 pandemic. Indirectly affect changes in work shifts and Cleaning Service Performance (Y2) Citimall Sukabumi. The Covid19 pandemic variable $(X)$ simultaneously and significantly has an influence on changes in work shifts (Y1) and Cleaning Service Performance (Y2).
\end{abstract}

Keywords: Covid-19 pandemic, Shift work, Cleaning Service Performance

\section{Pendahuluan}

Hampir setahun pandemic covid

19 mewabah di dunia, khususnya
Indonesia. Pendemi yang terus menerus ini telah membuat beberapa perusahaan gulung tikar, dan banyak orang kaya yang 
mendadak menjadi miskin. Pandemi ini tidak mengenal status, mau orang kaya ataupun rakyat jelata. Banyak yang kehilangan pekerjaan akibat kebijakan pemerintah yang melakkan PSBB dan lockdown. Banyak perusahaan yang memPHK karyawannya karena tidak sanggup lagi mebayar upah. Tentu saja masih ada perusahaan yang ingin bertahan sehingga harus mencari akal agar roda perusahaannya tetap berjalan tanpa harus merugikan siapapun.

Begitu juga dengan perusahaan Citimall Sukabumi, yang mana perusahaan yang merupakan pusat perbelanjaan yang menempati area seluas 1,5 hektar ini, menyediakan makanan dan minuman bagi pengunjung. Berlokasi di area yang sangat strategis, tepatnya Citimall berlokasi di Jalan Ahmad Yani No.121 - 127, Kecamatan Cikole, Kelurahan Gunung Guruh, Sukabumi - Jawa Barat. Citimall Sukabumi juga menawarkan beberapa tempat seperti kios dan counter bagi para penyewa untuk membuka usaha di kota ini, dengan memberikan fasilitas kebersihan yang tentunya dilakukan oleh karyawan bagian kebersihan dan melaksanakan pekerjaan dengan memberikan pelayanan kebersihan, baik di kantor, instansi atau perusahaan (Semesta, 2018).

Citimall Sukabumi juga terkena dampak dari mewabahnya virus covid 19 salah satunya sepinya pengungujung yang membuat berkurannya para tenat atau toko-toko retail yang mengontrak di mall ini. Untuk menyeimbangkan pemasukan dan pengeluaran maka pihak mall mengambil keputusan untuk mengurangi jam kerja karyawannya terutama karyawan yang bekerja di bagian kebersiahan atau Cleaning Service (CS). Tentu saja dengan perubahan shift kerja ini juga menyebabkan pemotongan gaji. Dimana sebelumnya para Cleaning Service ini digaji sesuai dengan upah UMR (Upah Minimum Ragional) daerah, sekarang dihitung berdasarkan pembagian sift kerjanya.

Tidak ada pilihan lain bagi Cleaning Service ini selain mengikuti aturan baru dari perusahaan. Namun sebagian mereka juga ada yang mengundurkan diri dan berusaha mencari pekerjaan lain. Sebelum pandemi mewabah, jumlah Cleaning Service di Citimall berjumlah 25 orang, namun sekarang hanya tersisa 10 orang saja. Dengan berkurangnya jumlah karyawan yang bekerja sebagai tenaga kebersihan ini, tentunya mereka harus bekerja lembur karena perusahaan telah merubah sistem shift kerja dari shift siang dan shift sore menjadi shift 2 hari kerja 2 hari libur. Ini berarti bahwa mereka bekerja dari pagi sampai malam selama 2 hari berturut-turut. Hal inilah jugalah yang menyebabkan kinerja mereka ikut berubah. Berdasarkan penjelasan diatas, maka dilakukan penelitian dengan judul "Dampak Pandemi covid 19 Terhadap Perubahan Shift Kerja dan kinerja Cleaning Service di Citimall Sukabumi."

Menurut Wikipedia, Pandemi covid19 adalah peristiwa menyebarnya penyakit korona virus 2019 (Bahasa Inggris: Coronavirus disease 2019, disingkat COVID-19) di seluruh dunia untuk semua Negara. Penyakit ini disebabkan oleh koronavirus jenis baru yang diberi nama SARS-CoV-2. Wabah covid-19 pertama kali ditemukan di Kota Wuhan, Provinsi Hubei, Tiongkok pada tanggal 1 Desember 2019, dan dinyatakan sebagai pandemi oleh Organisasi Kesehatan Dunia (WHO) pada tanggal 11 Maret 2020. Sementara menurut WHO (World Health Organization atau Badan Kesehatan Dunia) secara resmi menetapkan virus corona (COVID-19) sebagai pandemi pada tanggal 9 Maret 2020. Artinya, virus corona telah menyebar secara luas di dunia. Pandemi iniditakutkan karena penyebarannya yang meluas, bukan karena kegaasan penyakitnya.

Untuk menekan penyebaran covid 19 ini, maka pemerintah mengambil kebijakan dengan melakukan PSBB (Pembatasan Sosial Berskala Besar). Hal ini tentu saja berdampak pada siklus perekonomian, dimana masyarakat diharuskan di dalam rumah, kecuali kantor atau rumah sakit yang melayani masyarakat yang diperbolehkan buka dengan jam kerja yang terbatas. Toko-toko atau pasar yang menjual kebutuhan pokok pun masih di izinkan beroperasi asalkan tetap menjalankan protokol kesehatan. Beda halnya dengan toko atau pasar swalayan yang menjual pakaian jadi yan bukan termasuk kebutuhan pokok. Banyak pedagang yang bankrut karena kurangnya pembeli akibat takutnya pelanggan ke luar rumah.

Agar masyarakat bisa beraktifitas kembalai maka pemerintah memberlakukan "New Normal Life" atau beradaptasi dengan kebiasaan hidup yang baru. Undang undang tentang Panduan Pencegahan dan 
Pengendalian Covid 19 telah dikeluarkan oleh pemerintah dengan Surat Keputusan Menteri Kesehatan Republik Indonesia nomor HK 01.07/MENKES/328/2020 tanggal 20 Mei 2020.

Definisi shift kerja berbeda disetiap perusahaan atau perkantoran, ada yang memberlakukan shift pagi - sore, ada juga shift pagi - sore dan malam.

Menurut (Suma'mur, 2013), "shift kerja merupakan pola waktu kerja yang diberikan pada tenaga kerja untuk mengerjakan sesuatu oleh perusahaan dan biasanya dibagi atas kerja pagi, sore dan malam."

Sistem shift kerja biasanya dibagi 3 macam yaitu sistem kerja 2 shift adalah waktu kerja yang terbagi menjadi 2 bagian waktu yaitu pagi dan sore yang dimulai pukul $(07.00-$ 15.00) dan pukul (15.00 - 23.00), sistem kerja 3 shift adalah waktu kerja yang terbagi menjadi 3 bagian waktu yaitu pagi, sore dan malam hari dimulai pukul $(07.00-$ 15.00), (15.00 - 23.00) dan (23.00 - 07.00) yang ketiga adalah sistem non shift atau normal yaitu waktu kerja yang dilakukan hanya pada pagi sampai sore hari saja dimulai pukul $(08.00-16.00)$.

Pembagian Kerja Shift diatur dalam pasal 77 sampai pasal 85 UU No.13/2003 mengenai Ketenagakerjaan, jika jam kerja di sebuah perusahaan dibuat sebanyak 3 shift dengan masing-masing maksimal 8 jam per hari (termasuk jam istirahat), maka jumlah jam kerja secara akumulatif masingmasing shift tidak boleh lebih dari 40 jam per minggu.

Berdasarkan UU ketenagakerjaan diatas, dapat diasumsikan bahwa jumlah jam kerja tidak boleh lebih dari 40 jam, ini berarti sah-sah saja kalau perusahaan Citimall Sukabumi memberlakukan shift 22-2 atau 2 hari kerja, 2 hari libur selama tidak melebihi ketentuan jam kerja yang telah di atur dalam UU tersebut. Namun setiap pekerja yang bekerja melebihi ketentuan waktu kerja 8 jam/hari per-shift atau melebihi jumlah jam kerja akumulatif 40 jam per minggu, harus sepengetahuan dan dengan surat perintah (tertulis) dari pimpinan (management) perusahaan yang diperhitungkan sebagai waktu kerja lembur (Pasal 78 ayat 2 UU No.13/2003 tentang Ketenagakerjaan).

Kinerja berasal dari kata Job Performance atau actual performance yang berarti prestasi kerja atau prestasi sesungguhnya yang dicapai oleh seseorang. Pengertian kinerja adalah hasil kerja secara kualitas dan kuantitas yang dicapai oleh seorang pegawai dalam melaksanakan fungsinya sesuai dengan tanggung jawab yang diberikan kepadanya. Bernardin dan Russel dalam (Ruky, 2002) memberikan pengertian atau kinerja sebagai berikut : "performance is defined as the record of outcomes produced on a specified job function or activity during time period. Prestasi atau kinerja adalah catatan tentang hasil-hasil yang diperoleh dari fungsi-fungsi pekerjaan tertentu atau kegiatan selama kurun waktu tertentu.

Menurut (Gibson, 2003) Job performance atau kinerja adalah hasil dari pekerjaan yang terkait dengan tujuan organisasi, efisiensi dan kinerja kefektifan kinerja lainnya. Menurut (Sutrisno, 2017) (kinerja adalah "sebagai hasil yang telah dicapai seseorang dari tingkah kerjanya dalam melaksanakan aktivitas kerja". Sementara menurut (Edison, 2016) kinerja adalah hasil dari suatu proses yang mengacu dan diukur selama periode waktu tertentu berdasarkan ketentuan atau kesepakatan yang telah ditetapkan sebelumnya. Kinerja menjadi cerminan kemampuan dan keterampilannya dalam pekerjaan tertentu yang akan berdampak pada reward dari perusahaan.

Kinerja adalah hasil kerja yang dapat dicapai oleh seseorang atau kelompok orang dalam suatu perusahaan sesuai dengan wewenang dan tanggung jawab masing-masing dalam upaya pencapaian tujuan organisasi secara illegal, tidak melanggar hukum dan tidak bertentangan dengan moral dan etika (Afandi, 2018).

Maka dapat disimpulkan bahwa kinerja adalah hasil kerja seseorang atau kelompok yang telah dicapai baik secara kualitas maupun kuantitas sesuai dengan tanggung jawab yang diberikan.

Menurut Mangkunegara, 2002:68 Karakteristik orang yang mempunyai kinerja tinggi adalah sebagai berikut"

1. Memiliki tanggung jawab pribadi yang tinggi.

2. Berani mengambil dan menanggung resiko yang dihadapi.

3. Memiliki tujuan yang realitis.

4. Memiliki rencana kerja yang menyeluruh dan berjuang untuk meralisasi tujuannya.

5. Memanfaatkan umpan balik "feed back" yang konkrit dalam seluruh kegiatan kerja yang dilakukannya. 
6. Mencari kesempatan untuk merealisasikan rencana yang telag diprogramkan.

Menurut (Dharma, 2012) indikator kinerja adalah:

1. Konsisten: fokus akan suatu hal yang dikerjakan dan tidak berubah-ubah.

2. Tepat: menyelesaikan tugas atau pekerjaan secara benar.

3. Menantang: mengerjakan pekerjaan di luar pekerjaan yang biasa dilakukan.

4. Dapat diukur: dapat di nilai hasil kerja yang dikerjakan.

5. Dapat dicapai: pekerjaan yang dapat diselesaikan dengan baik.

6. Disepakati: disetujui pemberi kerja dan penerima pekerjaan.

7. Dihubungkan dengan waktu: mampu menyelesaikan semua tugas yang diberikan sesuai deadline yang ditentukan.

8. Berorientasikan kerja kelompok: mampu bekerjasama secara berkelompok dalam mengerjakan suatu tugas

Ada beberapa pengertian tentang kinerja karyawan yang dikemukakan oleh para ahli diantaranya:

1. Menurut Handoko dalam (Murty, 2012) "kinerja karyawan merupakan suatu hal yang sangat penting dalam suatu organisasi untuk mencapai tujuannya, sehingga berbagai kebijakan harus dilakukan organisasi untuk meningkatkan kinerja karyawannya."

2. Menurut (Afandi, 2018) Kinerja adalah hasil kerja yang dapat dicapai oleh seseorang atau kelompok orang dalam suatu perusahaan sesuai dengan wewenang dan tanggung jawab masingmasing dalam upaya pencapaian tujuan organisasi secara illegal, tidak melanggar hukum dan tidak bertentangan dengan moral dan etika.. "

Jadi Kinerja karyawan adalah hasil

dari kegiatan seorang karyawan yang dilakukan sesuai dengan kebijakan yan telah ditetapkan oleh perusahaan dalam mencapai tujuan.

Penelitian-penelitian tentang pengaruh Shift Kerja terhadap Kinerja Karyawan antara lain:

1. Penelitian oleh (Marsusanti, 2015) dalam Lingkungan Kerja Terhadap Kinerja Karyawan Matahari Department Store Kota Sukabumi. Hasil penelitian menunjukkan bahwa shift kerja secara empiris berpengaruh terhadap kinerja karyawan sebesar 0,354 artinya besarnya pengaruh shift kerja terhadap kinerja karyawan adalah sebesar $35,4 \%$, sedangkan sisanya dipengaruhi oleh variable lain.

2. Penelitian (Setiawan, 2020) dalam jurnalnya yang berjudul Pengaruh Perubahan Waktu Gilir Kerja Sebagai Dampak COVID 19 Terhadap Kinerja Karyawan. Hasil pengujian Moderate Regresi Analisys (MRA) didapatkan nilai $\mathrm{R}$ : 0,622 dengan Adjusted $\mathrm{R}$ square: 0,369 . Ini berarti menunjukkan bahwa Kinerja Pegawai dipengaruhi sebesar $36.9 \%$ oleh waktu gilir kerja.

Menurut (Robbins, 2010) faktorfaktor yang mempengaruhi kinerja karyawan dipengaruhi oleh sejumlah faktor antara lain:

1. Dasar-dasar perilaku individu yang meliputi karakteristik biografis, kemampuan dan pembelajaran.

2. Nilai, sikap dan kepuasan kerja

3. Komitmen

4. Persepsi dan pengambilan keputusan individu

5. Motivasi.

Sementara Menurut

Prawirosentono dalam (Damayanti, 2013), faktor yang mempengaruhi kinerja karyawan seperti pengetahuan, teknis, ketergantungan terhadap orang lain, kebijakan, kemampuan karyawan, kehadiran, kepemimpinan, dan bahkan minat yang akan membuat karyawan lebih mempunyai kemauan untuk meningkatkan kinerja mereka dengan sanagat baik dan berkualitas.

Kinerja karyawan yang berkualitas disebabkan karena adanya kemampuan, komunikasi, dan ketrampilan kerja karyawan. Dalam upaya peningkatan hasil pekerjaan yang lebih baik dibutuhkan sebuah penilaian kinerja. Daimna Penilaian kinerja adalah suatu proses yang dipakai oleh perusahaan untuk mengevaluasi pelaksanaan kerja karyawan. Karyawan perusahaan berusaha untuk merencanakan, mengatur, dan melaksanakan pekerjaan yang menjadi tanggung jawabnya. Tanggung jawab karyawan dalam bekerja nantinya akan mempunyai dampak yang positif untuk peningkatan kinerja apabila karyawan melakukan segala pekerjaannya dengan baik.

$\begin{array}{llr}\text { Indikator } & \text { kinerja digunakan } & \text { untuk } \\ \text { mengukur } & \text { keberhasilan } & \text { yang } \\ \text { menggambarkan } & \text { terwujudnya } & \text { kinerja, }\end{array}$


tercapainya hasil program dan hasil kegiatan.

Menurut (Kasmir, 2016) indikator yang digunakan untuk mengukur kinerja karyawan ada enam, yaitu:

1. Kualitas (mutu)

Kualitas merupakan suatu tingkatan di mana proses atau hasil dari penyelesain suatu kegiatan mendekati titik kesempurnaan. Makin sempurna suatu produk, maka kinerja makin baik, demikan pula sebaliknya jika kualitas pekerjaan yang dihasilkan rendah maka kinerjanya juga rendah.

2. Kuantitas (jumlah)

Untuk mengukur kinerja dapat pula dilakukan dengan melihat dari kuantitas (jumlah) yang dihasilkan oleh seseorang.

3. Waktu (jangka waktu)

Untuk jenis pekerjaan tertentu diberikan batas waktu dalam menyelesaikan pekerjaannya. Artinya ada pekerjaan batas waktu minimal dan maksimal yang harus dipenuhi.

4. Kerja sama antar karyawan

Kinerja sering kali dikaitkan dengan kerja sama antar karyawan dan antar pimpinan. Hubungan ini sering kali juga dikatakan sebagai hubungan antar perseorangan. Dalam hubungan ini diukur apakah seorang karyawan mampu untuk mengembangkan perasaan saling menghargai, niat baik dan kerja sama antara karyawan yang satu dengan karyawan yang lain.

5. Penekanan biaya

Biaya yang dikeluarkan untuk setiap aktivitas perusahaan sudah dianggarkan sebelum aktivitas dijalankan. Artinya dengan biaya yang sudah dianggarkan tersebut merupakan sebagai acuan agar tidak melebihi dari yang sudah dianggarkan.

6. Pengawasan

Dengan melakukan pengawasan karyawan akan merasa lebih bertanggung jawab atas pekerjaannya dan jika terjadi penyimpangan akan memudahkan untuk melakukan koreksi dan melakukan perbaikan secepatnya.

Sedangkan menurut Robbins,

2006:260" Indikator untuk mengukur kinerja karywan secara individu ada lima indikator yaitu:

1. Kualitas

kualitas kerja diukur dari persepsi karyawan terhadap kualitas pekerjaan yang dihasilkan serta kesempurnaan tugas terhadap keterampilan dan kemampuan karyawan.

2. Kuantitas

Kuantitas merupakan jumlah yang dihasilkan dinyatakan dalam istilah seperti jumlah unit, jumlah siklus aktivitas yang diselesaikan.

3. Ketepatan waktu

Ketepatan waktu merupakan tingkat aktivitas diselesaikan pada awal waktu yang dinyatakan, dilihat dari sudut koordinasi dengan hasil output serta memaksimalkan waktu yang tersedia untuk aktivitas lain.

4. Efektivitas

Efektivitas merupakan tingkat penggunaan sumber daya organisasi "tenaga, uang teknologi, bahan baku" dimaksimalkan dengamn maksud menaikkan hasil dari setiap unit dalam penggunaan sumber daya.

5. Kemandirian

Kemadirian merupakan tingkat seorang karyawan yang nantinya akan dapat menjalankan fungsi kerjanya Komitmen kerja. Merupakan suatu tingkat dimana karyawan mempunyai komitmen kerja dengan instansi dan tanggung jawab karyawan terhadap kantor.

\section{Metode Penelitian}

Metode yang dipakai dalam penelitian ini adalah metode deskriptif kuantitatif dengan menekankan penjelasan dan pengambaran masing-masing variabel yang sedang diteliti dengan memakai data yang berbentuk angka kemudian diikuti dengan menjelaskan korelasi atau hubungan kedua variabel tersebut menggunakan uji hipotesis.

Jenis penelitian ini menggunakan rumusan masalah asosiatif yaitu suatu rumusan masalah penelitian yang bersifat menanyakan hubungan antara dua variabel atau lebih.3 Variabel yang diangkat dalam penelitian ini meliputi variabel bebas (X1) dan (X2) variable terikat (Y). Variabel bebas (X) pada penelitian ini adalah Pandemi COVID 19 (X1) dan Shift Kerja (X2), Sedangkan variabel terikat $(Y)$ adalah Kinerja Karyawan.

\subsection{Populasi dan Sampel}

Menurut (Sugiyono, 2014) "populasi adalah wilayah generalisasi yang terdiri atas obyek/subyek yang mempunyai 
kualitas dan karakteristik tertentu yang ditetapkan oleh peneliti untuk dipelajari dan kemudian ditarik kesimpulannya." Populasi dari penelitian ini adalah Cleaning Service Citimall Sukabumi

Teknik pengambilan sampel pada penelitian ini dilakukan dengan cara sampling jenuh, yaitu teknik penentuan sampel bila anggota populasi digunakan sebagai sampel. Hal ini sering dilakukan bila jumlah populasi relative kecil, atau penelitian yang ingin membuat generalisasi dengan kesalahan yang sangat kecil. Istilah lain sampling jenuh adalah sensus, dimana semua anggota populasi dijadikan sebagai sampel (Sugiyono, 2014).

Sampel dari penelitian ini berjumlah 10 orang yang merupakan total keseluruhan populasi. Setelah jumlah sampel ditentukan, maka kuesioner akan diberikan kepada responden, kemudian uji validitas dan reliabilitas kuesioner setelah dinyatakan valid dan reliabel lanjut ke tahap pengolahan data menggunakan SPSS kemudian diambil kesimpulan.

Uji validitas dan reliabilitas diperlukan untuk menguji valid atau tidaknya data dari hasil rekapitulasi kuesioner dengan software SPSS. Setelah semua data dari hasil rekapitulasi kuesioner dinyatakan valid dan reliabel maka dilanjutkan dengan metode analisis data menggunakan SPSS.

Penelitian ini menggunakan 3 variabel, yaitu: variabel Pandemi COVID 19 (X1) dan variabel Shift Kerja (X2) dan variable Kinerja Karyawan (Y). Menurut Sugiyono (2013:38)" variabel adalah atribut atau sifat atau nilai dari orang, obyek atau kegiatan yang mempunyai variasi tertentu yang ditetapkan oleh peneliti untuk mempelajari variasi tertentu yang diterapkan oleh peneliti untuk dipelajari dan kemudian ditarik kesimpulannya."

Variabel independen adalah variabel yang mempengaruhi atau menjadi sebab perubahan atau timbulnya variabel dependen (terikat) (Sugiyono, Metode Penelitian Kuantitatif, Kualitatif, dan R\&D, 2013). Variabel independen sering disebut sebagai variabel yang mempengaruhi, variabel predictor, variabel bebas atau variabel tidak terikat. Sedangkan variabel dependen adalah variabel yang dipengaruhi atau yang menjadi akibat karena adanya variabel independen (variabel bebas).

Agar lebih memudahkan dalam melihat alur penelitian, maka dapat digambarkan kerangka pemikiran dari penelitian ini:

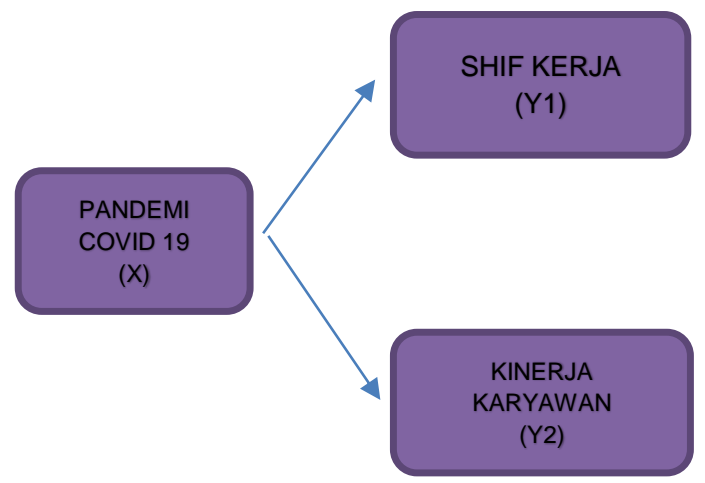

Sumber: Data primer yang diolah, (2021)

\section{Gambar 1. Kerangka Pemikiran}

Uji Hipotesisnya yaitu:

H1

Diduga ada pengaruh yang signifikan antara Pandemi COVID 19 (X1) terhadap Perubahan Shift Kerja (Y1).

$\mathrm{H} 2$

Diduga ada pengaruh yang signifikan antara Pandemi COVID 19 (X) terhadap Kinerja Cleanimg Service $(Y)$.

$\mathrm{H} 3$

Diduga ada pengarahuh secara simultan antara Pandemi COVID 19 (X) terhadapa Perubahan Shift Kerja (Y1) dan Kinerja Cleaning Service (Y2)

\subsection{Teknik Pengumpulan Data}

Teknik pengumpulan data adalah caracara yang digunakan untuk mengumpulkan data dan keterangan-keterangan lainnya dalam penelitian terhadap masalah yang menjadi objek penelitian. Adapun teknik pengumpulan data yang digunakan dalam penelitian ini adalah:

1. Penelitian Lapangan (Field Research)

Pengumpulan data dilakukan dengan cara melakukan survey langsung ke Citimall Sukabumi sebagai objek penelitian. Tujuan penelitian lapangan ini adalah untuk memperoleh data akurat. Adapun data yang diperoleh dengan cara penelitian meliputi:

a. Wawancara

Wawancara secara langsung antara peneliti dengan Cleaning Service berkaitan dengan penelitian yang akan dilakukan

b. Observasi

Mengumpulkan data dengan cara melakukan pengamatan secara 
langsung terhadap masalah yang berkaitan dengan penelitian, yaitu dampak pandemic COVID 19 terhadap perubahan shift kerja dan kinerja Cleaning Service. Observasi dilakukan dengan melakukan pengamatan langsung di lokasi penelitian yaitu Citimall Sukabumi JL. Ahmad Yani No.121-127

c. Kuesioner

Kuesioner atau daftar pertnyaan yaitu dengan cara membuat daftar pertanyaan yang kemudian di sebarkan pada responden secara langsung.

2. Studi Kepustakaan (Library Research)

Penelitian kepustakaan (library research) yaitu cara mengumpulkan data dengan mempelajari dan membaca literatur-literatur yang ada hubungannya dengan topik penelitian.

\subsection{Uji Instrument Penelitian}

Uji validitas dan realiabilitas merupakan uji yang dilakukan terhadap instrument penelitian. Kedua uji ini dilakukan untuk mengetahui apakah setiap instrument penelitian layak untuk dipakai dalam penelitian. Intrument penelitian disini yaitu merupakan kuesioner.

1. Uji Validitas

Uji Validitas adalah untuk mengetahui sah tidaknya instrumen kuesioner yang digunakan dalam pengumpulan data. Uji validitas ini dilakukan untuk mengetahui apakah itemitem yang tersaji dalam kuesioner benar benar mampu mengungkapkan dengan pasti apa yang akan diteliti.

Uji validitas dalam penelitian ini menggunakan program SPSS. Validititas suatu butir pertanyaan dapat dilihat pada hasil output SPSS pada tabel dengan judul Item-Total Statistic. Menilai kevalidan masing-masing butir pertanyaan dapat dilihat dari nilai Corrected item - Total Correlation masing-masing butir pertanyaan. Suatu butir pertanyaan dikatakan valid jika nilai $r$-hitung yang merupakan nilai dari Corrected item - Total Correlation > 0,30 (Priyatno, 2014). Maka butir dinyatakan valid, angka 0,3 merupakan nilai kritis validitas data dengan $\alpha=5 \%$.

2. Uji Reabilitas

Uji Reabilitas adalah Reliabilitas merupakan sejauh mana hasil pengukuran dengan menggunakan objek yang sama, akan menghasilkan data yang sama (Sugiyono, Metode Penelitian Kuantitatif, Kualitatif, dan R\&D, 2013).

$$
\text { Menurut (Ghozali, 2018) }
$$

reliabilitas adalah alat untuk mengukur suatu kuesioner yang merupakan indikator dari variabel atau konstruk. Suatu kuesioner dikatakan reliabel atau handal jika jawaban seseorang terhadap pernyataan adalah konsisten atau stabil dari waktu ke waktu. Adapun dasar pengambilan keputusan dalam uji reliabilitas adala sebagai berikut:

a. Jika nilai Cronbach's Alpha $>0,60$ maka angket (kuesioner) dinyatakan reliable atau constant.

b. Jika nilai Cronbach's Alpha $<0,60$ maka angket (kuesioner) dinyatakan tidak reliable atau constant

\subsection{Metode Analisis Data dan Uji Hipotesis}

Analisis data merupakan kegiatan setelah data dari seluruh responden atau sumber data lain terkumpul. Kegiatan dalam analisis data adalah mengelompokkan data berdasarkan variabel dan jenis responden, mentabulasi data berdasarkan variabel seluruh responden, menyajikan data setiap variabel yang diteliti, melakukan perhitungan untuk menjawab rumusan masalah dan melakukan perhitungan untuk menguji hipotesis yang tekah diajukan (Sugiyono, Metode Penelitian Kuantitatif, Kualitatif, dan $R \& D, 2013$ ).

Untuk pengolahan data dari hasil angket maka penulisan menggunakan metode skala likert. Skala Likert digunakan untuk mengukur sikap, pendapat, dan persepsi seorang atau sekelompok orang tentang fenomena sosial. Jawaban setiap item instrumen yang menggunakan skala Likert mempunyai gradasi yang sangat positif sampai negatif (Sugiyono, Metode Penelitian Kuantitatif, Kualitatif, dan R\&D, 2013). Terdapat lima kategori pembobotan dalam skala Likert sebagai berikut:

\section{Tabel 1 \\ Skala Model Likert}

\begin{tabular}{|c|c|}
\hline Alternative Jawaban & Bobot Nilai \\
\hline Sangat Setuju & 5 \\
\hline Setuju & 4 \\
\hline Kurang Setuju & 3 \\
\hline
\end{tabular}




\begin{tabular}{|c|c|}
\hline Tidak Setuju & 2 \\
\hline Sangat Tidak Setju & 1 \\
\hline
\end{tabular}

Sumber: (Sugiyono, 2013)

\subsection{Analisis Regresi Linear Berganda}

Dalam penelitian ini digunakan analisis regresi linier berganda, karena penelitian ini dilakukan untuk mengetahui Dampak Pandemi COVID 19 (X) terhadap Perubahan Shift Kerja (Y1) dan Kinerja Cleaning Service (Y2).

Besarnya pengaruh antara variabel independen terhadap variabel dependen dapat diketahui dengan menggunakan analisis regresi linier berganda. Untuk melihat hubungan dari kedua jenis variabel yang diteliti yaitu variabel $X$ dan variabel $Y$ menggunakan pengujian hipotesis atau uji t.

Hasil dari perhitungan statistik uji t (thitung) tersebut selanjutnya dibandingkan dengan ttabel. Dengan dk $=\mathrm{n}-2$ dan tingkat signifikannya yaitu $5 \%(=0,05)$, artinya jika hipotesis 0 (nol) ditolak dengan taraf kepercayaan 95\%, maka kemungkinan hasil dari penarikan kesimpulan mempunyai kebenaran 95\% dan hal ini menunjukkan adanya hubungan (korelasi) yang meyakinkan (signifikan) antara dua variabel tersebut.

Untuk mengetahui ditolak atau tidaknya dinyatakan dengan kriteria jika $t$ hitung > t tabel, maka $\mathrm{HO}$ ada di daerah penolakan, berarti $\mathrm{Ha}$ diterima artinya terdapat pengaruh antara pandemi COVID 19 terhadap perubaan shift kerja dan kinerja cleaning service. Kemudian jika $t$ hitung < t tabel, maka $\mathrm{HO}$ ada di daerah penerimaan, berarti Ha ditolak, artinya tidak terdapat pengaruh antara pandemic covid 19 terhadap perubahan shift keja dan kinerja cleaning service.

Analisa hipotesis apakah semua variabel independen yang dimasukkan dalam model mempunyai pengaruh secara bersama-sama terhadap variabel dependen dengan menggunakan uji $\mathrm{F}$ dengan kriteria taraf signifikan $\alpha=0,05$ dan kriteria pengujian dimana $\mathrm{Ha}$ diterima apabila $\mathrm{p}$ value $<\alpha$ dan Ha ditolak apabila $p$ value $>$ a.

\section{Hasil dan Pembahasan}

\subsection{Karakteristik Responden}

Karakteristik

responden

dikelompokkan menurut umur dan pendidikan terakhir. Sesuai dengan dengan hal tersebut uraian mengenai karakteristik responden dalam penelitian ini sebagai berikut:

Tabel 2

\section{Karakteristik Responden Berdasarkan Jenjang Pendidikan}

\begin{tabular}{|c|c|c|c|}
\hline No & Pendidikan & Jumlah & Persentase \\
\hline 1 & SD & $\mathbf{1}$ & $\mathbf{1 0 \%}$ \\
\hline 2 & SMP & $\mathbf{4}$ & $\mathbf{4 0 \%}$ \\
\hline 3 & SMA & $\mathbf{5}$ & $\mathbf{5 0 \%}$ \\
\hline
\end{tabular}

Berdasarkan data dari tabel di atas, terlihat bahwa karakteristik responden berdasarkan pendidikan yang dijadikan sampel dalam penelitian ini yaitu, dengan responden berpendidikan SD sebanyak 1 orang atau sebanyak $10 \%$, kemudian responden dengan pendidikan SMP yaitu sebanyak 4 orang atau sebanyak $40 \%$, Sedangkan responden berpendidikan SMA sebanyak 5 orang atau sebanyak $50 \%$. Dengan demikian responden terbanyak yang dijadikan sampel dalam penelitian ini adalah responden yang berpendidikan SMA.

Tabel 3

\section{Karakteristik Responden Berdasarkan} Jenjang Umur

\begin{tabular}{|c|c|c|c|}
\hline NO & Umur & Jumlah & Persentase \\
\hline 1 & $18-25$ & $\mathbf{2}$ & $\mathbf{2 0} \%$ \\
\hline 2 & $26-35$ & $\mathbf{7}$ & $\mathbf{7 0} \%$ \\
\hline 3 & $36-45$ & $\mathbf{1}$ & $\mathbf{1 0} \%$ \\
\hline
\end{tabular}

Pada tabe; 3 diatas, dapat dilihat bahwa karakteristik responden berdasarkan umur yaitu, dengan responden umur antara 18 - 2 sebanyak 2 orang atau sebanyak $20 \%$, kemudian responden dengan umur antara 26 - 35 yaitu sebanyak 7 orang atau sebanyak $70 \%$, Sedangkan responden umur antara $36-45$ sebanyak 1 orang atau sebanyak $10 \%$. Terbanyak yang dijadikan sampel adalah yang berusia antara 26 - 35

\subsection{Uji Validitas Instrument}

Uji validitas digunakan untuk menguji sejauh mana ketepatan atau kebenaran suatu instrument sebagai alat ukur variabel penelitian. Jika alat ukur valid atau benar maka hasil pengukuranpun pasti akan benar, atau dengan kata lain, validitas berbicara tentang bagaimana suatu alat ukur yang digunakan memang telah mengukur apa yang ingin diukur. 
Pengujian validitas instrumen penelitian ini dengan menggunakan rumus korelasi person (pearson correlation bivariate). Uji validitas Pandemi COVID 19 (X) dilakukan terhadap 10 (sepuluh) indikator dengan data sampel (n) 10 responden. Kriteria validasi adalah jika koefisien korelasi bernilai $>0,3$, maka butir dinyatakan valid, angka 0,3 merupakan nilai kritis validitas data dengan $\alpha=5 \%$

Peringkat setiap variabel penelitian dapat dilihat dari perbandingan antara skor aktual dengan skor ideal dengan didasarkan pada nilai rata-rata dan dikategorikan dengan rentang skor minimum $=1$ dan skor maksimum $=5$, maka lebar skala 5-1 $5=0,8$, dengan kategori skala:

Tabel 4.

Skala Kategori

\begin{tabular}{|c|c|}
\hline Skala & Keterangan \\
\hline $1,00-1,80$ & Sangat renda \\
\hline $1,81-2,60$ & Rendah \\
\hline $2,60-3,40$ & Sedang \\
\hline $3,41-4,20$ & Tinggi \\
\hline $4,20-5,00$ & Sangat tinggi \\
\hline
\end{tabular}

Sumber: Sugiyono, (2014)

Tabel 5.

Uji Validitas Instrumen Pandemo COVID $19(X)$

\begin{tabular}{|c|c|c|c|}
\hline Pernyataan & $\begin{array}{c}\text { r Dengan } \\
\text { RataRata }\end{array}$ & $\begin{array}{c}\text { Nilai } \\
\text { Kritis }\end{array}$ & Keterangan \\
\hline $\mathbf{1}$ & 0,713 & 0.3 & Valid \\
\hline $\mathbf{2}$ & 0,876 & 0.3 & Valid \\
\hline $\mathbf{3}$ & 0,576 & 0.3 & Valid \\
\hline $\mathbf{4}$ & 0,778 & 0.3 & Valid \\
\hline $\mathbf{5}$ & 0,432 & 0.3 & Valid \\
\hline $\mathbf{6}$ & 0,712 & 0.3 & Valid \\
\hline $\mathbf{7}$ & 0,876 & 0.3 & Valid \\
\hline $\mathbf{8}$ & 0,412 & 0.3 & Valid \\
\hline $\mathbf{9}$ & 0,843 & 0.3 & Valid \\
\hline $\mathbf{1 0}$ & 0,712 & 0.3 & Valid \\
\hline
\end{tabular}

Sumber: Data primer yang diolah, (2021)

Nilai kritis ( $r$ ) di ambil dari tabel kritis 0,3 pada $n=10$ dan $\alpha 0,05(5 \%)$ Hasil dari 10 (sepuluh) butir pernyataan indikator dinyatakan valid, artinya 10 butir pernyataan tersebut dapat mengukur apa yang hendak di ukur yaitu mengukur variabel X Pandemi COVID 19.
Tabel 6.

Uji Validitas Instrumen Perubahan Shift Kerja (Y1)

\begin{tabular}{|c|c|c|c|}
\hline Pernyataan & $\begin{array}{c}\text { r Dengan } \\
\text { RataRata }\end{array}$ & $\begin{array}{c}\text { Nilai } \\
\text { Kritis }\end{array}$ & Keterangan \\
\hline $\mathbf{1}$ & 0,635 & 0.3 & Valid \\
\hline $\mathbf{2}$ & 0,872 & 0.3 & Valid \\
\hline $\mathbf{3}$ & 0,854 & 0.3 & Valid \\
\hline $\mathbf{4}$ & 0,718 & 0.3 & Valid \\
\hline $\mathbf{5}$ & 0,779 & 0.3 & Valid \\
\hline $\mathbf{6}$ & 0,800 & 0.3 & Valid \\
\hline $\mathbf{7}$ & 0,823 & 0.3 & Valid \\
\hline $\mathbf{8}$ & 0,474 & 0.3 & Valid \\
\hline $\mathbf{9}$ & 0,402 & 0.3 & Valid \\
\hline $\mathbf{1 0}$ & 0,463 & 0.3 & Valid \\
\hline
\end{tabular}

Sumber: Data primer yang diolah, (2021)

Nilai kritis ( $r$ ) di ambil dari tabel kritis 0,3 pada $n=10$ dan $\alpha 0,05(5 \%)$ Hasil dari 10 (sepuluh) butir pernyataan indikator dinyatakan valid, artinya 10 butir pernyataan tersebut dapat mengukur apa yang hendak di ukur yaitu mengukur variabel $\mathrm{Y} 1$ perubahan shift kerja.

Tabel 7.

Uji Validitas Instrumen Kinerja Cleaning Service (Y2)

\begin{tabular}{|c|c|c|c|}
\hline $\begin{array}{c}\text { Pernyata } \\
\text { an }\end{array}$ & $\begin{array}{c}\mathrm{r} \\
\text { Dengan } \\
\text { RataRa } \\
\text { ta }\end{array}$ & $\begin{array}{c}\text { Nila } \\
\mathrm{i} \\
\text { Kriti } \\
\mathrm{s}\end{array}$ & $\begin{array}{c}\text { Keterang } \\
\text { an }\end{array}$ \\
\hline $\mathbf{1}$ & 0,649 & 0.3 & Valid \\
\hline $\mathbf{2}$ & 0,395 & 0.3 & Valid \\
\hline $\mathbf{3}$ & 0,707 & 0.3 & Valid \\
\hline $\mathbf{4}$ & 0,776 & 0.3 & Valid \\
\hline $\mathbf{5}$ & 0,492 & 0.3 & Valid \\
\hline $\mathbf{6}$ & 0,692 & 0.3 & Valid \\
\hline $\mathbf{7}$ & 0,570 & 0.3 & Valid \\
\hline $\mathbf{8}$ & 0,435 & 0.3 & Valid \\
\hline $\mathbf{9}$ & 0,520 & 0.3 & Valid \\
\hline $\mathbf{1 0}$ & 0,832 & 0.3 & Valid \\
\hline
\end{tabular}

Sumber: Data primer yang diolah, (2021)

Nilai kritis ( $r$ ) di ambil dari tabel kritis 0,3 pada $n=10$ dan $\alpha 0,05(5 \%)$ Hasil dari 10 (sepuluh) butir pernyataan indikator dinyatakan valid, artinya 10 butir pernyataan tersebut dapat mengukur apa yang hendak di ukur yaitu mengukur variabel Y2 Kinerja Cleaning Service. 


\subsection{Uji Reliabilitas}

Uji reliabilitas digunakan untuk menguji apakah pernyataan yang diberikan memiliki jawaban yang konsisten sehingga dapat dipercaya bahwa pernyataan tersebut dapat digunakan sebagai alat pengumpul data. Pernyataan spekulatif diperbolehkan, asal berdasarkan fakta bukan imajinasi.

Tabel 8

Hasil Uji Reliabilitas

\begin{tabular}{|c|c|c|}
\hline \multicolumn{3}{|c|}{ Reliability Statistics } \\
\hline & Cronbach's & \\
\hline & Alpha Based & \\
\hline & on & \\
\hline Cronbach's & Standardized & \\
\hline Alpha & Items & $\mathrm{N}$ of Items \\
\hline .777 & .764 & 10 \\
\hline
\end{tabular}

Sumber: Data primer yang diolah (2021)

Dari tabel diatas, diketahui $\mathrm{N}$ of items (banyaknya butir pertanyaan angket) ada 10 items dengan Cronbach's alpha 0,777 . Karena nilai Cronbach's Alpha 0,777 $>0,60$ maka sebagaimana dasar pengambilan keputusan uji reliabilitas, maka ke 10 item tersebut dinyatakan reliabilitas atau konsisten.

\subsection{Uji Normalitas}

Tabel 9.

Hasil Uji Normalitas

One-Sample Kolmogorov-Smirnov Test

Unstandardize d Residual

\begin{tabular}{llr}
\hline $\mathrm{N}$ & & 10 \\
\hline Normal Parameters ${ }^{\mathrm{a}, \mathrm{b}}$ & Mean & .0000000 \\
\cline { 2 - 3 } & Std. Deviation & 5.30687620 \\
\hline $\begin{array}{l}\text { Most Extreme } \\
\text { Differences }\end{array}$ & Absolute & .148 \\
\cline { 2 - 3 } & Positive & .148 \\
\cline { 2 - 3 } & Negative & -.120 \\
\hline Test Statistic & & .148 \\
\hline
\end{tabular}

\begin{tabular}{ll}
\hline Asymp. Sig. (2-tailed) & $.200^{c, d}$ \\
\hline
\end{tabular}

Sumber: Data primer yang diolah, (2021)

Hasil uji normalitas melalui OneSample Kolmogorov-Smirnov Test menunjukkan nilai asymp. Sig. (2-tailed) diperoleh nilai signifikansi sebesar 0,200 $(0,200>0,05)$, maka berdasarkan NPar 1sample K-S dapat katakan bahwa untuk data yang digunakan berdistribusi normal.

\subsection{Analisa Koefisien Korelasi}

Seberapa besar dampak Pandemi COVID 19 terhadap Perubahan Shift Kerja dan Kinerja Cleaning Service, maka datadata yang telah didapatkan selama penelitian akan di analisis dengan metode Korelasi Pearson.

Tabel 10.

Hasil Analisa Koefisien Korelasi

\begin{tabular}{|l|l|}
\hline Variabel & Pandemi covid 19 \\
\hline $\begin{array}{l}\text { Perubahan Shift } \\
\text { Kerja }\end{array}$ & 0,645 \\
\hline $\begin{array}{l}\text { Kinerja Cleaning } \\
\text { Service }\end{array}$ & 0,675 \\
\hline
\end{tabular}

Sumber: Data primer yang diolah (2021)

Hasil analisis dengan uji korelasi pearson terhadap nilai korelasi Pandemi covid 19 (X) dengan \{erubahan Shift Kerja ( $Y 1$ ) sebesar $r=0,645$ yang berarti berada di antara nilai +/- 0,51 - 0,75 maka hubungannya cukup kuat dan searah. Nilai korelasi Pandemi COVID 19 (X) dengan Kinerja Cleaning Service (Y2) sebesar $r=$ 0.675 yang berarti berada di antara nilai +/0,51 - 0,75 maka memiliki hubungan sangat kuat dan searah.

\subsection{Analisa Koefisien Determinasi dan Regresi Linier Berganda \\ Koefisien determinasi bertujuan untuk mengetahui besarnya pengaruh Pandemi COVID 19 terhadap Perubahan Shift Kerja danKinerja Cleaning Service.}

Tabel 11

Hasil Uji Koefisien Determinasi

\begin{tabular}{|l|c|}
\hline \multicolumn{1}{|c|}{ Variabel } & R Square \\
\hline Perubahan shift kerja & 0,308 \\
\hline Kinerja cleaning service & 0,415 \\
\hline
\end{tabular}

Sumber: Data primer yang diolah (2021) 


\begin{abstract}
R-square bernilai antara $0-1$ dengan ketentuan semakin angka mendekati 1 berarti semakin baik. Jika RSquare bernilai 0.6 berarti $60 \%$ sebaran variabel dependen dapat dijelaskan oleh variabel independen. Sisanya $40 \%$ tidak dapat dijelaskan oleh variabel diluar variabel independen (komponen error).

$$
\text { Besarnya nilai koefisien }
$$

determinasi ( $R$ Square) perubahan shift kerja (Y1) adalah 0,308 atau sama dengan $30,8 \%$ artinya jika variabel perubahan shift kerja (Y1) naik sebesar 1 poin maka akan menyebabkan nilai dari dampak pandemic covid 19 (X) naik sebesar 0,308 dan memiliki pengaruh searah atau positif.

$$
\text { Besarnya nilai koefisien }
$$
determinasi ( $\mathrm{R}$ Square) Kinerja cleaning service (Y2) adalah 0,415 atau sama dengan $41,5 \%$ artinya jika variabel Kinerja cleaning service (Y2) naik sebesar 1 poin maka akan menyebabkan nilai dari dampak pandemic covid 19 (X) naik sebesar 0,415 dan memiliki penaruh searah atau positif.
\end{abstract}

\subsection{Uji t}

Uji t digunakan untuk mengetahui apakah dalam model regresi variabel independen secara parsial berpengaruh signifikan terhadap variabel dependen atau tidak. Hasil uji $t$ dampak pengaruh pandemic covid $19(\mathrm{X})$ terhadap perubahan shift kerja (Y1) signifikansi $0,00<0,05$, atau thitung >ttabel dengan $n-k(10-2)$, sehingga $2,141>1,860$ dengan taraf signifikansi 0,05 maka dapat disimpulkan bahwa $\mathrm{H} 0$ ditolak dan $\mathrm{H} 1$ diterima. Ini artinya bahwa terdapat dampak yang signifikan dari Pandemi covid 19 (X) terhadap perubahan shift kerja (Y1). Hasil uji t dampak pengaruh pandemic covid 19 $(\mathrm{X})$ terhadap Kinerja Cleaning Service $(\mathrm{Y})$ dengan signifikansi $0,00>0,05$, atau thitung > ttabel, sehingga $1,917>1,860$ maka dapat disimpulkan maka $\mathrm{H} 0$ ditolak dan $\mathrm{H} 2$ diterima, ini artinya bahwa terdapat dampak pandemic covid 19 (X) berpengaruh terhadap Kinerja Cleaning Service $(Y)$.

\subsection{Uji F}

Uji $F$ bertujuan untuk menguji pengaruh Pandemi 19 (X1) terhadap perubahan Shift Kerja (Y1) dan Kinerja Cleaning Service(Y2) secara simultan (bersama-sama).
Tabel 12

\section{Hasil Uji F}

\begin{tabular}{|l|l|l|}
\cline { 2 - 3 } \multicolumn{1}{c|}{} & F & Sig \\
\hline Regresi & 14,098 & 0,000 \\
\hline Signifikansi $=5 \%(0,05)$ \\
\hline
\end{tabular}

Berdasarkan tabel di atas, dapat diketahui bahwa signifikansi $0,000<0,05$ dan Fhitung (F-stat) sebesar 14,098, Nilai ini dibandingkan dengan nilai Ftabel pada tabel distribusi $F$, dengan demikian $\alpha=$ 0,05 , df $=(\mathrm{k} ; 1 \mathrm{n}-\mathrm{k})=(2 ; 10-2)=(2 ; 8)$. Kemudian untuk pengujian dua sisi (twotailed) di peroleh nilai Ftabel sebesar 4,48. Diketahui bahwa Fhitung $(14,098)>$ Ftabel $(4,48)$ atau Fhitung $>$ Ftabel, sehingga $\mathrm{HO}$ ditolak (H1 diterima). Artinya terdapat pengaruh yang secara simultan dan signifikan dari variabel Pandemi covid 19(X) terhadap Perubahan Shift Kerja(Y1) dan Kinerja Cleaning Servicei (Y2).

\section{Kesimpulan}

Kesimpulan yang dapat diambil adalah bahwa secara parsial Pandemi COVID $19 \quad(\mathrm{X})$ berdampak signifikan terhadap Perubahan Shift Kerja (Y1), artinya setiap dampak yang diakibatkan oleh pandemic covid 19 secara tidak langsung mempengaruhi perubaan shift kerja dan Kinerja Cleaning Service (Y2) Citimall Sukabumi. Variabel Pandemi covid 19 (X) secara simultan dan signifikan memiliki pengaruh terhadap perubahan shift kerja (Y1) dan Kinerja Cleaning Service (Y2).

\section{References}

Afandi, P. (2018). Manajemen Sumber Daya Manusia (Teori, Konsep, dan indikator). Riau: Zanafa Publishing.

Damayanti, d. (2013). Pengaruh Kompensasi dan Motivasi Terhadap Kinerja Karyawan Perusahaan Daerah Air Minum (PDAM). Surakarta: Jurnal UNS Vol 2 No 1 Hal 155 s/d 168.

Dharma, S. (2012). Manajemen Kinerja Falsafah Teori dan Penerapannya. Yogyakarta: Pustaka Pelajar.

Edison, E. (2016). Manajemen Sumber daya Manusia. Bandung: Alfabeta.

Ghozali, I. (2018). Aplikasi Analisis Multivariate dengan Program IBM 
SPSS 25. Semarang: Universitas Diponegoro.

Gibson, d. (2003). Organizations: Behavior Structure Processes Eleventh Edition. New York: Mc Graw Hill.

Kasmir. (2016). Manajemen Sumber Daya Manusia (Teori dan Praktik). Depok: PT Rajagrafindo Persada.

Marsusanti, E. (2015). Pengaruh Shift dan Lingkungan kerja Terhadap Kinerja Karyawan. Sukabumi: Jurnal Swabumi, Vol. 2 No. 29-35 .

Murty, H. (2012). Pengaruh Kompensasi, motivasi, dan Komitmen Organisasional Terhadap Kinerja Karyawan Bagian Akuntansi (Studi Kasus Pada Perusahaan Manufaktur Di Surabaya). Surabaya: The Indonesian Accounting Review Vol. 2 STIE Perbanas.

Robbins, S. P. (2010). Manajemen Edisi Kesepuluh. Jakarta: Erlangga.

Ruky, A. S. (2002). Sistem Manajemen Kinerja. Jakarta: PT. Gramedia Pustaka Utama.
Semesta. (2018). Cleaning Service atau Penyedia Jasa Kebersihan. Bandung: Citra Insani Garuda.

Setiawan, B. S. (2020). Pengaruh Waktu Gilir Kerja Sebagai Dampak Covid19 Terhadap Kinerja Karyawan. Tangerang: Jurnal Manajemen Pendidikan dan IImu Sosial.

Sugiyono. (2013). Metode Penelitian Kuantitatif, Kualitatif, dan R\&D. Bandung: Alfabeta.

Sugiyono. (2014). Metode Penelitian Bisnis. Bandung: Alfabeta.

Suma'mur. (2013). Higienis Perusahaan dan Kesehatan Kerja. Jakarta: Sagung Seto.

Sutrisno, E. (2017). Manajemen Sumber Daya Manusia. Jakarta: Kencana. 